\title{
PENCEGAHAN KEJADIAN KARDIOVASKULER PADA PASIEN DIABETES MELLITUS TIPE 2.
}

\author{
Indah Serinurani Effendi*
}

\begin{abstract}
Abstrak
WHO memprediksi adanya peningkatan angka insiden dan prevalensi Diabetes Mellitus (DM) tipe2 diberbagai penjuru dunia . Untuk Indonesia, WHO meprediksi kenaikan jumlah pasien dari 8,4 juta pada tabun 2000 menjadi sekitar 21,3 juta pada tabun 2030. Suatu jumlah yang sangat besar dan merupakan beban yang sangat berat untuk dapat ditangani sendiri oleh dokter spesialis/ sub spesialis, maka perlu strategi pelayanan kesehatan primer sebagai ujung tombak menjadi sangat penting untuk lebib berperan dalam penanganan DM sederbana dan mencegah terjadinya penyulit DM, antara lain risiko penyakit kardiovaskuler.

Perlu penangan terpadu pada penyakit tidak menular dan berkesinambungan. Dibutubkan kontrol rutin antara lain gula darah puasa $<130 \mathrm{mg} / \mathrm{dl}$, gula darah 2jpp <200 mg/dl, HbA1c <7, Tensi 130/80 mm Hg, Total cholesterol < $200 \mathrm{mg} / \mathrm{dl}$, Kholesterol $L D L<160 \mathrm{mg} / \mathrm{dl}$, Kholesterol HDL $>50 \mathrm{mg} / \mathrm{dl}$. Disamping itu perlu menilai risiko Kardiovaskuler dengan Framingham Risk Score (FRS).
\end{abstract}

Kata kunci : Diabetes Mellitus, Risiko Kardiovaskuler, Framingham Risk Score.

\section{PENDAHULUAN}

Diabetes mellitus (DM) merupakan penyakit kronik yang diderita seumur hidup. Dalam pengelolaan penyakit tersebut selain dokter, perawat ,ahli gizi serta tenaga kesehatan lain ,peran pasien dan keluarga menjadi sangat penting . Edukasi kepada pasien dan keluarganya guna memahami lebih jauh tentang perjalanan penyakit DM, pencegahan, penyulit DM ,dan penatalaksanaannya akan sangat membantu meningkatkan keikutsertaan mereka dalam usaha memperbaiki hasil pengelolaan.

Salah satu penyulit DM adalah penyakit jantung. Perkembangan penyakit DM menunjukkan adanya kecenderungan peningkatan insiden dan prevalensi penyakit DM diberbagai penjuru dunia. Berdasarkan data Badan Pusat Statistik Indonesia tahun 2003 prevalensi DM pada daerah urban ( Jakarta ) sebesar 14,7\% , sedang tahun 1993 prevalensi DM 5,7 \% ,diperkirakan tahun 2030 nanti akan ada 21,3 juta penduduk Indonesia yang berusia diatas 20 tahun penyandang DM. Berbagai penelitian menunjukkan adanya kecenderungan peningkatan angka insiden dan prevalensi DM type2. Suatu jumlah yang sangat besar dan merupakan beban yang sangat besar untuk dapat ditangani sendiri oleh dokter spesialis /subspesialis bahkan oleh semua tenaga kesehatan yang ada.
Dalam strategi pelayanan kesehatan bagi penyandang DM, menempatkan pelayanan kesehatan primer sebagai ujung tombak, peran dokter umum menjadi sangat penting untuk mencegah terjadi penyulit DM dalam hal ini penyakit jantung dan pembuluh darah.

\section{Patofisiologi}

Pada dinding endotel pembuluh darah terdapat keseimbangan antara vasokonstriksi dan vasodilatasi serta antara proliferasi dengan anti proliferasi. Pada pasien DM , perokok, hiperlipidemi dan hipertensi keseimbangan endotel tersebut terganggu dengan peningkatan endothelin (ET-1) dan penurunan Nitrit Oxide (NO) . Akibatnya terjadi vasokonstriksi, agregasi platelet, adhesi leukosit, peningkatan permeabilitas serta proliferasi VSMC, sehingga penanganan pasien DM harus dilakukan secara komprehensif bahkan sebelum menjadi Penyakit DM misalnya pasien Impaires Glucose Tolerance (IGT) harus segera diterapi karena dapat meningkatkan risiko coronary arterial disease. Sambil menunggu diagnosa DM ditegakkan perlu pencegahan dan penyuluhan tentang DM agar tidak terjadi komplikasi dan monitoring penyakitnya secara periodik dan terpadu.

\footnotetext{
* Staff Pengajar Pada Fakultas Kedokteran

Universitas Mubammadiyah Malang
} 


\section{Pencegahan}

Penanganan penyakit DM bukan hanya penanganan kadar glukosa darahnya saja tetapi faktor risiko lain yang dapat memicu risiko terjadinya penyakit jantung dan pembuluh darah antara lain: hipertensi, hiperlipidemia, merokok . Maka perlu pemeriksaan berkala yang lain yaitu: kadar $\mathrm{Hb}$ A1c ,hipertensi, HDL-C , LDL-C , Trigliserida, Obesitas abdomen.

Untuk penanganan pasien DM perlu pengaturan faktor risiko lain yang dapat memicu terjadinya risiko kardiovaskuler, antara lain:

1 Kadar HbA1c untuk mengetahui prognosis $\mathrm{DM}$

2 Kadar total kholesterol $<200 \mathrm{mg} / \mathrm{dl}$ 3 Kadar HDL-C yaitu kholesterol darah yang memiliki aktifitas anti infeksi, menghambat transportasi kholesterol, anti inflamasi, anti trombotik ,anti apoptotic dan anti oksidan. Oleh karena itu peningkatan $1 \%$ HDL-C dapat mengurangi risiko kardiovaskuler sebesar 3\%

4 Kadar LDL-C yaitu kholesterol yang merugikan, penurunan 1\% LDL-C dapat mengurangi risiko kardiovaskuler sebesar 1\%.

5 Obesitas Abdomen merupakan salah satu gejala resistensi insulin, akibatnya terjadi gangguan keseimbangan lipid, intoleransi glukosa, hipertensi, dan pembentukan aterosklerosis . Keadaan ini bisa menimbulkan infark miokard dan kematian mendadak. Lingkar perut wanita idealnya $80 \mathrm{~cm}$ dan pria $90 \mathrm{~cm}$.

5 Hipertensi. Tensi yang ideal adalah sistole $<$ $130 \mathrm{mmHg}$, diastole $<80 \mathrm{mmHg}$. Untuk mencapai target penurunan tekanan darah pada pasien DM bisa diberikan obat anti hipertensi lebih dari satu jenis, sehingga bisa mengurangi risiko kardiovaskuler.

Dalam penanganan DM dan risiko penyakit kardiovaskuler yang menyertainya, kita harus mengenal pasien seutuhnya dengan melihat peluang dan hambatannya. Pasien dan keluarga juga harus dilibatkan, misalnya pemberian resep obat bagus dan mahal pada pasien tidak mampu akan menyebabkan obat tidak terbeli dan pasien tidak sembuh, sehingga perlu komunikasi yang baik agar tidak memperparah kondisi pasien. Keadaan pasien juga harus dijelaskan agar pasien mengerti dengan kondisinya dan mau bekerja sama dengan dokter untuk mengatasi penyakitnya. Dokter juga harus selalu mengikuti perkembangan terbaru penanganan DM dan faktor risiko yang menyertainya. Baik pengalaman individual dokter maupun bukti klinis dari luar sama-sama penting dalam seni pengobatan seorang dokter.

\section{DAFTAR PUSTAKA}

Departemen Kesehatan Republik Indonesia. Riset Kesehatan Dasar. 2007.

Hendrawan, Dadang. New Strategy for Management Dyslipidemia: Inbibiting Cholesterol Absorbtion Oral Production. In: Pendidikan Kedokteran Berkelanjutan Kardiologi dan Kedokteran Vaskuler X. 2011: Malang. 1-37.

Konsensus Pengelolaan dan Pencegahan Diabetes Mellitus tipe II di Indonesia. Perkumpulan Endokrinologi Indonesia. 2006; 1-37.

Pikir, Budi Susetyo. In: Pendidikan Kedokteran Berkelanjutan Kardiologi dan Kedokteran Vaskuler XIII. 2011: Surabaya. 182-186

Soemantri, Djoko. Managing Cardiovascular Risk in Patient with Type II Diabetes: Chalenge and Oportunity. In: Pendidikan Kedokteran Berkelanjutan Kardiologi dan Kedokteran Vaskuler XIII. 2011: Surabaya. 1-20

Supriadi, Pawik. Risk Management in Cardiovascular Disease: The Important of Reality Target Goal. In: Pendidikan Kedokteran Berkelanjutan Kardiologi dan Kedokteran Vaskuler X. 2011: Malang. 16-19. 